ORIGINAL ARTICLE

\title{
Screening for Hypothyroidism in children with severe acute malnutrition at Nutrition Rehabilitation Center, Children's Hospital and Institute of Child Health Multan.
}

\author{
Saadia Khan ${ }^{1}$, Waqas Imran Khan², Ayesha Fayyaz ${ }^{3}$, Ibad $\mathrm{Ali}^{4}$, Asad Abbas ${ }^{5}$, Reema Arshad ${ }^{6}$
}

Article Citation: Khan S, Khan WI, Fayyaz A, Ali I, Abbas A, Arshad R. Screening for Hypothyroidism in children with severe acute malnutrition at Nutrition Rehabilitation center, Children's Hospital and Institute of Child Health Multan. Professional Med J 2022; 29(1):116-120.

https://doi.org/10.29309/TPMJ/2022.29.01.5722

ABSTRACT... Objective: To determine the percentage of Hypothyroidism in children with severe acute malnutrition. Study Design: Cross Sectional study. Setting: Nutrition Rehabilitation Center, Children's Hospital and Institute of Child Health Multan. Period: January 2019 to December 2019. Material \& Methods: A total of 255 malnourished patients (as per inclusion criteria) were included in current study. A written Performa was designed to collect history, anthropometric measurements and systemic examination. Taking aseptic measures venous blood was sent for baseline tests as well as for T3, T4 and TSH, total serum protein albumin and total ferritin levels to hospital laboratory. Correlation between serum thyroid concentrations and total protein, albumin, hemoglobin and serum ferritin were estimated by using t-test and p-vlaue less than 0.05 was considered as significant. Total collected data was entered and analyzed in SPSS version 21.0. Results: A total of 255 malnourished children were included in this study. Majority of studied subjects were male (52.5\%) with $83.92 \%$, 3-5 years of age. Amongst the 255 children mean values of T3 in MAM and SAM patients were $105.4 \mathrm{ng} / \mathrm{dl}$ and $89.7 \mathrm{ng} / \mathrm{dl}$ respectively. There was a statistically significant $(p<0.001)$ association between decreased T3 and type of malnutrition. Similarly, mean values of T4 in MAM and SAM patients were $6.3 \mathrm{ug} / \mathrm{dl}$ and $5.7 \mathrm{ug} / \mathrm{dl}$ respectively that was statistically significant $(\mathrm{p}<0.05)$. Lower values of T4 were higher among SAM children in 1 to 3 years age group compared to respective MAM children with $p$ value .0 .05 and high T4 value in 3-5 years age group of MAM children were both statistically insignificant. Higher mean Values of TSH was found in SAM compared to MAM children both age groups. Conclusion: Severe acute malnutrition (SAM) is associated with reduction in T3 and T4 levels and higher levels of TSH in SAM children as compared to MAM. The altered thyroid hormone status in children with PEM is perhaps a protective phenomenon to limit protein catabolism and lower energy requirements.

Key words: $\quad$ Hypothyroidism, Severe Acute Malnutrition, T3, T4, TSH.

\section{INTRODUCTION}

PEM is one of the most prevalent nutritional problem of developing countries of the World. It is the major contributor of under-five mortality and morbidity. ${ }^{1,2}$ The World Health Organization $(\mathrm{WHO})$ reported that malnutrition is leading cause of $60 \%$ deaths in developing countries in children aged less than five years. ${ }^{3}$ National nutritional survey 2018 estimated that in Pakistan every fourth child out of ten is stunted i.e. $40.2 \%$ and $17.7 \%$ children are suffering from wasting with $28.9 \%$ are underweight. ${ }^{4}$

Malnutrition is basically cellular imbalance between supply of nutrients and energy in daily diet that not only effects physical health but also permanently affects mental and endocrinal development of child. ${ }^{5,6}$ Severe acute malnutrition brings number of reductive adaptations in the body and effects metabolism like sodiumpotassium pump imbalance and decrease in circulatory protein levels. ${ }^{7}$

As hemostatic mechanism of body is compromised in children with Malnutrition, it effects biosynthesis of various hormones especially thyroid hormone metabolism. Thyroid hormone plays an important role in regulation of
1. MD, Assistant Professor Preventive Pediatrics, Children's Hospital and The Institute of Child Health, Multan. 2. FCPS, Associate Professor Pediatric Endocrinology, Children's Hospital and The Institute of Child Health, Multan. 3. FCPS, Assistant Professor General Pediatrics, Children's Hospital and The Institute of Child Health, Multan. 4. FCPS, Associate Professor Preventive Pediatrics, Children's Hospital and The Institute of Child Health, Multan. 5. BS (Human Nutrition and Dietetics), Student, IFNS, BZU, Multan.

6. MSc, Research Associate, Aga Khan University, Karachi.

\author{
Correspondence Address: \\ Dr. Saadia Khan \\ Department of Preventive Pediatrics \\ Children's Hospital and The Institute of Child \\ Health, Multan. \\ doctorsaadiakhan1479@gmail.com
}

Article received on: Accepted for publication:

$27 / 07 / 2020$ $09 / 06 / 2021$ 
various body functions and necessary for growth and development. Hypothyroidism (low serum thyroid levels) causes problems in physical and mental health and retardation with short stature. ${ }^{8}$

Previous studies reported that PEM develops marked changes in secretion, metabolism and thyroid structure. It reduces activity of thyroid glands and decreases T3 and T4 secretions secondary to changes in iodine metabolism and reduced circulatory proteins. ${ }^{9,10}$

Local data regarding prevalence and burden of hypothyroidism and its correlation of total protein and albumin levels in severely acute malnourished children is deficient. In this study an attempt has been made to study the levels of T4, T3, Thyroid stimulating hormone (TSH) in children with SAM and MAM and its correlation with serum total protein and albumin levels.

\section{MATERIAL \& METHODS}

It was cross sectional hospital based descriptive study which is carried out in malnourished children aged 1 to 5 years admitted at Nutrition Rehabilitation centre (NRC), Children's Hospital and Institute of Child Health Multan from January 2019 to December 2019. Prior to this study, proper approval from hospital institutional committee was taken. An informed written consent was taken from parents or guardians. A total of 255 malnourished patients (as per inclusion criteria) were included in current study.

\section{Inclusion Criteria}

- All the children fulfilling the criteria of SAM and MAM, those admitted at NRC and whose parents/guardians gave consent were included in this study.

\section{Exclusion Criteria}

- Critically ill patients transferred to intensive care unit.

- Patients with underlying chronic diseases such as celiac disease, thalassemia etc.

- Not willing to participate in research and give consent.

A written performa was designed to collect history, anthropometric measurements and systemic examination. Taking aseptic measures venous blood was sent for baseline tests as well as for T3, T4 and TSH, total serum protein albumin and total ferritin levels to hospital laboratory. Total collected data was entered and analyzed in SPSS version 21.0. Descriptive statistics was applied for categorical data. Lower levels of T3, T4, TSH, serum protein, hemoglobin and serum ferritin in children with SAM and MAM were primary outcome variables. In addition to this, correlation between serum thyroid concentrations and total protein, albumin, hemoglobin and serum ferritin was estimated by using t-test and p-vlaue less than 0.05 was considered as significant.

\section{Operational Definitions}

- Severe acute malnutrition were defined as weight for height <-3SD or mid upper arm circumference $<11.5 \mathrm{~cm}$ or presence of any bilateral edema.

- Moderate acute malnutrition with weight for height <-2SD or mid upper arm circumference $11.5-12.5 \mathrm{~cm}$ at OTP

\section{RESULTS}

A total of 255 malnourished children who fulfill the inclusion criteria were included in this study. Majority of studied subjects were male (52.5\%) with $83.92 \% \% 3-5$ years of age.

\begin{tabular}{|l|c|c|}
\hline Characteristics & $\begin{array}{c}\text { Frequency } \\
(\mathbf{n = 2 5 5 )}\end{array}$ & Percentage (\%) \\
\hline Gender & 142 & 56.8 \\
\hline Male & 113 & 43.2 \\
\hline Female & 41 & 16.4 \\
\hline Age group & 214 & 83.92 \\
\hline 1-3 years & & \\
\hline 3-5 years & \multicolumn{2}{|c|}{ Table-I. Gender and Age distribution of studied } \\
\multicolumn{2}{|c|}{ subjects. (n=255) } \\
\hline
\end{tabular}

Amongst the 255 children mean values of T3 in MAM and SAM patients were $105.4 \mathrm{ng} / \mathrm{dl}$ and $89.7 \mathrm{ng} / \mathrm{dl}$ respectively. There was a statistically significant $(p<0.001)$ association between decreased T3 and type of malnutrition. Similarly, mean values of T4 in MAM and SAM patients were $6.3 \mathrm{ug} / \mathrm{dl}$ and $5.7 \mathrm{ug} / \mathrm{dl}$ respectively that was 
statistically significant $(p<0.05)$.

Amongst the 255 children mean values of T3 in MAM and SAM patients were $105.4 \mathrm{ng} / \mathrm{dl}$ and $89.7 \mathrm{ng} / \mathrm{dl}$ respectively. There was a statistically significant $(p<0.001)$ association between decreased T3 and type of malnutrition. Similarly, mean values of T4 in MAM and SAM patients were $6.3 \mathrm{ug} / \mathrm{dl}$ and $5.7 \mathrm{ug} / \mathrm{dl}$ respectively that was statistically significant $(p<0.05)$.

\begin{tabular}{|l|c|c|c|c|}
\hline \multicolumn{1}{|c|}{ Parameters } & $\begin{array}{c}\text { SAM } \\
\text { (Mean } \pm \text { SD) }\end{array}$ & $\begin{array}{c}\text { MAM } \\
\text { (Mean } \pm \text { SD) }\end{array}$ & $\begin{array}{c}\text { Median } \\
\text { (Mean } \pm \text { SD) }\end{array}$ & P-Value \\
\hline T3 & $89.7 \pm 3.4$ & $105.4 \pm 12.2$ & $97.55 \pm 7.8$ & $<0.01$ \\
\hline T4 & $5.7 \pm 1.3$ & $6.3 \pm 2.2$ & $6.0 \pm 3.5$ & $<0.01$ \\
\hline TSH & $1.93 \pm 1.2$ & $2.2 \pm 1.1$ & $2.06 \pm 1.15$ & $>0.05$ \\
\hline Total Protein & $4.5 \pm 0.39$ & $5.2 \pm 0.32$ & $4.85 \pm 0.55$ & $<0.01$ \\
\hline Albumin & $2.2 \pm 0.3$ & $2.9 \pm 0.4$ & $2.55 \pm 0.35$ & $<0.01$ \\
\hline Hemoglobin & $8.7 \pm 2.2$ & $10.4 \pm 2.3$ & $9.55 \pm 2.25$ & $>0.05$ \\
\hline Serum iron & $75.32 \pm 10.8$ & $77.44 \pm 11.9$ & $76.35 \pm 11.35$ & $<0.01$ \\
\hline
\end{tabular}

Table-III represents age wise distribution of mean of T3 among SAM and MAM children low T3 value was higher among MAM children in 3 year and above age group compared to respective SAM children with $p$ value $<0.05$ which is statistically significant.

\begin{tabular}{|l|c|c|c|}
\hline \multicolumn{1}{|c|}{ Age group } & $\begin{array}{c}\text { SAM } \\
\text { (Mean } \pm \text { SD) }\end{array}$ & $\begin{array}{c}\text { MAM } \\
\text { (Mean } \pm \text { SD) }\end{array}$ & $\begin{array}{c}\text { Median } \\
\text { (Mean } \pm \text { SD) }\end{array}$ \\
\hline 1-3 years & $96.2 \pm 2.9$ & $106.2 \pm 13.8$ & $101.2 \pm 8.35$ \\
\hline 3-5 years & $89.7 \pm 3.3$ & $102.8 \pm 11.9$ & $96.25 \pm 7.6$ \\
\hline
\end{tabular}

Table-III. Association of malnutrition with T3 by age (mean T3).

Table-IV represents age wise distribution of mean of T4 among SAM and MAM children. Lower values of T4 was higher among SAM children in 1 to 3 years age group compared to respective MAM children with $p$ value $<.0 .05$ and high T4 value in 3-5 years age group of MAM children were both statistically insignificant.

\begin{tabular}{|l|c|c|c|}
\hline \multicolumn{1}{|c|}{ Age group } & $\begin{array}{c}\text { SAM } \\
\text { (Mean } \pm \text { SD) }\end{array}$ & $\begin{array}{c}\text { MAM } \\
\text { (Mean } \pm \text { SD) }\end{array}$ & $\begin{array}{c}\text { Median } \\
\text { (Mean } \pm \text { SD) }\end{array}$ \\
\hline 1-3 years & $6.4 \pm 0.7$ & $5.8 \pm 2.4$ & $6.1 \pm 1.55$ \\
\hline 3-5 years & $5.5 \pm 1.02$ & $6.5 \pm 2.2$ & $6.0 \pm 1.61$ \\
\hline
\end{tabular}

Table-IV. Association of malnutrition with T4 by age (mean T4).

Higher mean Values of TSH was found in SAM compared to MAM children in 1 to 3 years age group as well as 3 to 5 year age group.

\begin{tabular}{|l|c|c|c|}
\hline \multicolumn{1}{|c|}{ Age group } & $\begin{array}{c}\text { SAM } \\
\text { (Mean } \pm \text { SD) }\end{array}$ & $\begin{array}{c}\text { MAM } \\
\text { (Mean } \pm \text { SD) }\end{array}$ & $\begin{array}{c}\text { Median } \\
\text { (Mean } \pm \text { SD) }\end{array}$ \\
\hline 1-3 years & $1.7 \pm 0.29$ & $1.49 \pm 0.5$ & $1.59 \pm 0.39$ \\
\hline 3-5 years & $2.2 \pm 0.92$ & $1.7 \pm 0.9$ & $1.95 \pm 1.82$ \\
\hline & \multicolumn{4}{|c|}{ Table-V. Association of malnutrition with TSH by age } \\
(mean TSH).
\end{tabular}

\section{DISCUSSION}

Protein energy malnutrition is prevalent in developing countries and leads to failure in homeostasis mechanism of body of children at every system. Globally, malnutrition is directly or indirectly associated with under five mortality. It also affects the hormonal system especially thyroid hormones which imparts important role in energy and protein metabolism. Present study was conducted to know about thyroid hormone levels in children with malnutrition.

Current study estimates that serum albumin, total protein and thyroid profile are low in malnourished children. Previous studies show that malnutrition is significantly -associated with thyroid harmone imbalance. ${ }^{11-13}$ Kumar $S$ et al, conducted a study on 60 -children's which reported that malnutrition leads to decrease serum T3 and T4 levels. ${ }^{14}$

Current study reported that mean $\pm S D$ values of T3, T4 and TSH were lower $(97.55 \pm 7.8,6.0 \pm 3.5$ and $2.06 \pm 1.15$ respectively) as compared to standard values. Low mean thyroid values 
indicates that protein energy malnutrition is the major issue and high protein is needed for proper functioning of thyroid hormones. Similar studies were conducted by Mehta Set al, and Abrol $\mathrm{P}$ et al, which reported that mean value of serum T3 and TSH were significantly high $122.5 \mathrm{ng} / \mathrm{dl}$ and $2.51 \mathrm{mIU} / \mathrm{l} ; 107.7 \mathrm{ng} / \mathrm{dl}$ and 2.6 $\mathrm{mIU} / \mathrm{l}$ respectively. ${ }^{15,16}$ Mean serum T4 levels were also higher $9.18 \mathrm{ug} / \mathrm{dl}$ and $8.3 \mathrm{ug} / \mathrm{dl}$ respectively as compared to current study. Our results was comparable with the study conducted by Lazarus $M$ et al, which report the mean value of T3, T4 and $\mathrm{TSH}$ were $99.3 \mathrm{ng} / \mathrm{dl}, 6.0 \mathrm{ug} / \mathrm{dl}$ and $2.0 \mathrm{mlU} / \mathrm{l}$ respectively. ${ }^{13}$

We estimate that majority of patients (47.2\%) belong to 2-4 years of age. Contradictory findings were reported by Lazarus $\mathrm{M}$ et al where majority of children (43.8\%) belong to 2-4 years of age. ${ }^{13}$ Another study reported that majority of malnourished children (52.5\%) were less than two years of age. ${ }^{17}$ A comparative study conducted by Dhanyal GS et al which reported lowest level of serum albumin and total protein $3.4 \mathrm{gm} / \mathrm{dl}$ and $5.9 \mathrm{gm} / \mathrm{dl}$ respectively. ${ }^{18}$

Mean values of T3 in MAM and SAM patients were $105.4 \mathrm{ng} / \mathrm{dl}$ and $89.7 \mathrm{ng} / \mathrm{dl}$ respectively (Table-II) which were significantly associated with type of malnutrition $(p<0.001)$. The mean values of T4 in MAM and SAM patients were $6.3 \mathrm{ug} / \mathrm{dl}$ and $5.7 \mathrm{ug} / \mathrm{dl}$ respectively (Table-II). We observed the mean values of TSH (Table-II) in MAM and SAM patients were $2.2 \mathrm{mlU} / \mathrm{I}$ and $1.93 \mathrm{mlU} / \mathrm{I}$ respectively in the present study. The levels were within normal limits. There was no significant $(p<0.32)$ association between TSH and type of malnutrition. Kumar $S$ et $\mathrm{al}^{4}$ studied effect of malnutrition on thyroid Hormone, he concluded that with increasing severity of malnutrition, the serum concentration of T3 and T4 progressively decreased and that of serum TSH increased. ${ }^{14}$ Dhanjal GS et al also concluded that the levels of biochemical variables, decreases as the severity of malnutrition increases. ${ }^{18}$

\section{CONCLUSION}

Severe acute malnutrition (SAM) is associated with reduction in T3 and T4 levels and higher levels of TSH in SAM children as compared to MAM. The altered thyroid hormone status in children with PEM is perhaps a protective phenomenon to limit protein catabolism and lower energy requirements.

Copyright $(0) 09$ June, 2021.

\section{REFERENCES}

1. Rodríguez L, Cervantes E, Ortiz R. Malnutrition and gastrointestinal and respiratory infections in children: A public health problem. International journal of environmental research and public health. 2011; 8(4):1174-205.

2. World Health Organization. Global burden of proteinenergy malnutrition in the year 2000. Geneva: World Health Organization; 2006.

3. Rahman A, Hossain MM. Quantile regression approach to estimating prevalence and determinants of child malnutrition. Journal of Public Health. 2020; 23:1-7.

4. Ministry of National Health Services, Regulations and Coordination. Government of Pakistan. National Nutrition Survey 2018. Pakistan: UNICEF; 2018. Website: [https://www.unicef.org/pakistan/nationalnutritionsurvey-2018]. Retrieved on: June 14, 2019.

5. Martins VJ, Toledo Florêncio TM, Grillo LP, Do Carmo P Franco M, Martins PA, Clemente AP, Santos CD, Vieira MD, Sawaya AL. Long-lasting effects of under nutrition. International journal of environmental research and public health. $2011 ; 8(6): 1817-46$.

6. Freijer K, Tan SS, Koopmanschap MA, Meijers JM, Halfens RJ, Nuijten MJ. The economic costs of disease related malnutrition. Clinical nutrition. 2013:1; 32(1):136-41.

7. Millward DJ. Nutrition, infection and stunting: The roles of deficiencies of individual nutrients and foods, and of inflammation, as determinants of reduced linear growth of children. Nutrition research reviews. 2017; 1;30(1):50.

8. Gupta S, Chaurasiya OS. Evaluation of Thyroid Functions in Severely Malnourished Children. International Journal of Research and Review. 2019; 6(6):199-202.

9. Sah SP, Arora M, Kumar S, Batra J, Mustafa I, Yadav L. Effect of PEM on thyroid status, serum total protein and $A / G$ ratio in pre-school going children. International Journal of Research in Medical Sciences. 2017; 5(10):4486. 
10. Sandeep M, Krishnamurthy B. Thyroid hormone status in children with protein energy malnutrition. International Journal of Contemporary Pediatrics. 2016; 3(1):193-9.

11. G. Coulthard M. Oedema in kwashiorkor is caused by hypoalbuminaemia. Paediatrics and International Child Health. 2015; 35(2):83-89.

12. Bartz S, Mody A, Hornik C, Bain J, Muehlbauer M, Kiyimba T, Kiboneka E, Stevens R, Bartlett J, St Peter JV, Newgard CB, Freemark M. Severe acute malnutrition in childhood: Hormonal and metabolic status at presentation, response to treatment, and predictors of mortality. J Clin Endocrinol Metab. 2014; 99(6):212837.

13. Lazarus M, Kashyap AK, Borkar R, Ajmariya M. Study of thyroid profile in malnourished children $(6$ months - 5 years) admitted in the nutritional rehabilitation centre and paediatric ward NSCB Medical College Jabalpur, India. Int J Contemp Pediatr 2018; 5:1072-7.
14. Kumar S, Nandkarni J, Dwivedi R. Thyroid hormone status in malnourished children. Indian Pediatr. 2009; 46:263-4.

15. Mehta S. Thyroid hormone status in children with severe acute malnutrition. EJPMR. 2017; 4(4):592-4.

16. Abrol P, Verma A, Hooda HS. Thyroid hormone status in protein energy malnutrition in Indian children. Indian J Clin Biochem. 2001; 16(2):221-3.

17. Chakraborty S, Gupta SB, Chaturvedi B, Chakraborty SK. A study of protein energy malnutrition (PEM) in children ( 0 to 6 year) in a rural population of Jhansi district (UP). Indian J Comm Med. 2006; 31(4):291.

18. Dhanjal GS, Singh M. Thyroid hormone status in children with protein energy malnutrition a hospital based case control study. Int J Contemp Pediatr. 2017; 4(2):351-5.

\begin{tabular}{|c|c|c|c|}
\hline \multicolumn{4}{|c|}{ AUTHORSHIP AND CONTRIBUTION DECLARATION } \\
\hline No. & Author(s) Full Name & Contribution to the paper & Author(s) Signature \\
\hline 1 & Saadia Khan & Prepared topic, Basic methodology. & 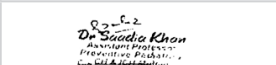 \\
\hline 2 & Waqas Imran Khan & $\begin{array}{l}\text { Data collection, Statistical analysis, } \\
\text { Research. }\end{array}$ & 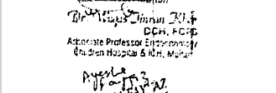 \\
\hline 3 & Ayesha Fayyaz & Manuscript writing. & 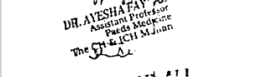 \\
\hline 4 & Ibad Ali & Manuscript writing, Review & 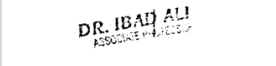 \\
\hline 5 & Asad Abbas & References writing, Data collection. & Ascas \\
\hline 6 & Reema Arshad & $\begin{array}{l}\text { Quality insurance Review of } \\
\text { literature. }\end{array}$ & 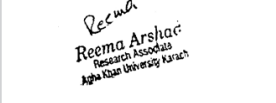 \\
\hline
\end{tabular}

